\title{
SIKAP PEMUSTAKA TERHADAP PROGRAM OPAC JURNAL DALAM MEMPERMUDAH PENELUSURAN PADA PERPUSTAKAAN UNIVERSITAS PENDIDIKAN GANESHA
}

\author{
N P Pramita Utami \\ UPT. Perpustakaan, Universitas Pendidikan Ganesha \\ Singaraja, Indonesia \\ email: pramitautami@yahoo.com
}

\begin{abstract}
Abstrak
Tujuan penelitian ini untuk memerikan sikap pemustaka terhadap keberadaan program OPAC jurnal yang dikaji melalui skema triadik yang meliputi aspek kognitif, afektif dan konasi. Untuk mencapai tujuan tersebut, maka metode penelitian deskriptif dengan pendekatan survey digunakan dalam penelitian ini. 100 responden pemustaka dijadikan sebagai sampel penelitian yang didapat dengan teknik accidental sampling. Data dikumpulkan melalui angket, wawancara, dan observasi. Data yang terkumpul kemudian dianalisis secara deskriptif. Hasil penelitian ini menunjukkan bahwa sikap pemustaka secara umum dapat dikategorikan positif yaitu dengan rerata $84,15 \%$. Sikap positif tersebut secara rinci dapat diuraikan sebagai berikut: (1) aspek kognitif sebesar $85 \%$, sehingga dikategorikan sangat positif; (2) aspek afektif sebesar $82,45 \%$, sehingga dikategorikan positif; dan (3) aspek konasi sebesar $85,37 \%$, sehingga dikategorikan sangat positif. Dalam pembentukan sikap tersebut, ketiga komponen sikap ini terkait satu sama lain. Komponen sikap kognitif (pengetahuan, kepercayaan, dan keyakinan) pemustaka akan mewarnai aspek afektif (perasaan suka/tidak suka), sehingga akan membingkai kecenderungan perilaku pemustaka (aspek konasi) terhadap OPAC Jurnal. Berdasarkan hasil yang diperoleh, untuk membentuk sikap positif dan mengurangi keraguan sikap pemustaka untuk menggunakan OPAC Jurnal, maka perlu diupayakan keterlibatan pimpinan untuk mengadakan kegiatan sosialisasi dan bimbingan teknis secara berkelanjutan.
\end{abstract}

Kata-kata kunci: afektif, kognitif, konasi, program OPAC jurnal, sikap pemustaka.

\begin{abstract}
The aim of the research was to describe the user's attitude towards OPAC journal program, which was analyzed through triadic components consisting of cognitive, affective and conative aspects. To achieve the purpose of the research, then a descriptive research through survey approach was applied. 100 respondents were used as the research samples obtained from accidental sampling technique. The data were collected through questionaire, interview and observation. Then, the collected data were analyzed descriptively. The result of the research showed that the user's attitude was categorized as positive in general with the avarage of $84,15 \%$. It is further specified for each component as the following: (1) $85 \%$ (very
\end{abstract}


positive) for kognitive aspect; (2) $82,45 \%$ (positive) for affective aspect; and (3) $85,37 \%$ (very positive) for conative aspect. Those three attitude component are attached one another to develop the user's attitude. The knowledge, believe and trust (kognitive aspect) will colour the the feeling (affective aspect), whether it is like or dislike to frame the user's behaviour tendency (conative aspect) toward the OPAC Journal. Based on the result, it is considered necessary to socialize and to give technical support continuously for the development of OPAC Journal in the attempt to construct a positive user's attitude as well as to reduce the feeling of doubt to use the instrument.

Key words: affective, cognitive, conation, OPAC journal program, user's attitude

\section{PENDAHULUAN}

Hasil penelitian oleh Utami (2012) untuk mengembangkan program OPAC berbasis Subject Indexing untuk mempermudah penelusuran koleksi jurnal pada perpustakaan Universitas Pendidikan Ganesha telah berhasil mengembangkan program tersebut sesuai dengan kondisi ideal yang diharapkan. Secara ringkas penelitian tersebut telah melakukan tiga hal, yaitu: (1) mengembangkan program OPAC jurnal berbasis subject indexing, (2) memvalidasi program tersebut melalui pemustaka, pustakawan dan programmer, dan (3) mengukur efektivitas program.

Program OPAC jurnal berbasis subject indexing dapat dikategorikan cukup baik yang dalam pengembangannya programmer menggunakan program XAMPP. Program didesain dengan melalui beberapa langkah seperti: identifikasi masalah, pembuatan prototype, validasi, dan ujicoba program.

Program OPAC jurnal berbasis subject indexing, walaupun masih memiliki beberapa kelemahan, secara umum sudah cukup baik, andal, fleksibel, mudah dioperasikan dan cukup memuaskan. Hal ini berarti bahwa program tersebut bisa menyelesaikan tugasnya dengan cukup akurat. Selain itu, isi dan tampilan OPAC juga cukup informatif, jelas dan menarik, sehingga pemustaka dapat memahami isi OPAC dengan baik.

Hasil ujicoba juga menunjukkan bahwa program OPAC jurnal berbasis subject indexing mampu mempermudah penelusuran jurnal. Hal ini bisa diketahui dengan membandingkan waktu/lamanya penelusuran antara menggunakan katalog manual dan menggunakan katalog digital berupa OPAC.

Kebermanfaatan program OPAC ini ditunjukkan oleh respons positif dari pemustaka sebagai pemakai program, programmer, dan pustakawan. Selanjutnya, dari hasil validasi ditunjukkan bahwa pengembangan program OPAC ini cukup bagus dan perlu untuk dikembangkan sehingga nantinya layak untuk diaplikasikan pada sistem IT di perpustakaan. Ditunjukkan pula efektivitas program yang sangat efektif dalam mempermudah pemustaka dalam penelusuran artikel yang diinginkan dengan berbantuan teknologi. Pemustaka dapat dengan mudah mengakses topik/subjek yang dicari dengan mengetikkan kata kunci pada kolom searching secara cepat dan tepat tanpa harus mengetahui nama, edisi dan tahun jurnal. Selain mempermudah

Jurnal IImu Sosial dan Humaniora | 460 
pemustaka, pustakawan pengelola layanan jurnal dan terbitan berseri juga sangat dibantu dalam membimbing pemustaka melakukan penelusuran artikel serta dalam memasukkan data jurnal baru secara otomatis.

Dalam proses uji coba program pada sampel terpilih, berbagai respons muncul dari pihak pemustaka maupun pustakawan/petugas. Kecenderungan respons positif diberikan oleh sebagian besar pemustaka yang umumnya menyukai program OPAC. Namun demikian, dalam proses try out itu pula, ada pemustaka yang merasa canggung dalam memanfaatkan teknologi tersebut. Dengan bimbingan petugas dalam mengenalkan program, akhirnya pemustaka tersebut merasakan kebermanfaatan program. Dengan dimudahkannya pemustaka sekaligus pihak pustakawan dalam menelusur dan memasukkan data jurnal baru, maka pemanfaatan koleksi jurnal pun dapat dimaksimalkan. Selain itu, pustakawan yang bertugas di bagian jurnal juga dapat menata koleksi dengan mudah karena pemustaka tidak perlu lagi mengobrak-abrik seluruh koleksi guna memperoleh artikel yang dicari.

Berdasarkan hasil angket dan wawancara, ada kecenderungan pemustaka untuk lebih menyukai katalog online dibandingkan dengan bentuk manual. Mereka berasumsi bahwa keberadaan teknologi sebagai pendukung di setiap lini kehidupan mereka sangat penting karena sifatnya yang praktis, efektif dan efisien. Hal ini sesuai dengan adanya transformasi kultural menuju masyarakat informasi, yang mana segala akses informasi yang serba cepat dan tepat berguna demi kelangsungan hidup di dunia (Hamad:
2010). Perilaku penggunaan katalog online inilah yang menjadi pertimbangan peneliti dalam kajian mengenai sikap pemustaka.

Dalam Cambridge Advance Learner's Dictionary edisi ke -3 (2010), sikap/attitude adalah sebuah perasaan atau pendapat tentang sesuatu atau orang atau cara bertindak berdasarkan sesuatu. Selanjutnya, Baron dan Byrne (2007) menyatakan bahwa sikap adalah suatu evaluasi kita terhadap berbagai aspek dunia sosial, yang memunculkan rasa suka maupun tidak suka kita terhadap issue, ide, kelompok sosial maupun objek tertentu. Selanjutnya, Rokeach dalam Suhardi, B (1996) memberikan definisi yang lain tentang sikap. Menurut Rokeach sikap adalah tata kepercayaan yang secara relatif berlangsung lama mengenai suatu objek atau situasi yang mendorong seseorang untuk menanggapinya dengan cara tertentu yang disukainya. Rokeach juga menyebutkan ada tiga komponen sikap yaitu kognitif, afektif dan perilaku. Jadi dapat disimpulkan bahwa sikap penggunaan OPAC sebagai media penelusuran adalah evaluasi pemustaka terhadap program OPAC mengenai perasaan suka maupun tidak suka atas program tersebut.

Bertolak pada pentingnya kajian terdahulu dan menimbang efektivitas program, maka peneliti berupaya untuk mengadakan penelitian lebih lanjut mengenai sikap pemustaka terhadap program OPAC berbasis subject indexing. Hal ini dilakukan untuk meninjau lebih dalam mengenai sikap penggunaan program OPAC sebagai media penelusuran. Dengan demikian, dapat diidentifikasikan bahwa permasalahan utama kajian ini adalah,

Jurnal IImu Sosial dan Humaniora | 461 
"Bagaimanakah sesungguhnya sikap pemustaka terhadap keberadaan program OPAC berbasis subject indexing ditinjau dari aspek kognitif, afektif dan konasi?". Kecenderungan suka ataupun tidak suka terhadap program tersebut akan menjadi suatu evaluasi atas penerimaan teknologi.

\section{METODE PENELITIAN}

\section{Desain Penelitian}

Penelitian ini bertujuan untuk menjelaskan ikhwal masalah atau objek tertentu secara rinci sehingga disebut penelitian deskriptif (Suyanto:2007). Deskripsi sikap pemustaka terhadap program OPAC jurnal berbasis subject indexing merupakan produk penelitian ini. Dengan demikian dapat dijelaskan bahwa objek kajian penelitian adalah respons pemustaka dan respons pustakawan, sedangkan subjeknya adalah pemustaka dan pustakawan. Pendekatan yang digunakan dalam penelitian ini adalah survei. Survei merupakan suatu desain penelitian kuantitatif yang mana "peneliti mensurvei sejumlah sampel atau seluruh populasi untuk melukiskan sikap, opini, perilaku dan karakteristik populasi tersebut" (Creswell, 2008: 388).

\section{Populasi dan Sampel}

Populasi penelitian ini adalah seluruh pemustaka dari perpustakaan Universitas Pendidikan Ganesha. Sampel penelitian adalah sebanyak 100 orang pemustaka yang menggunakan program OPAC dalam menelusur jurnal. Rancangan pengambilan sampelnya menggunakan rancangan nonprobabilitas dengan teknik pengambilan sampel aksidental. Menurut Faisal (2008), accidental sampling merupakan teknik pengambilan sampel "asal ambil atau asal pilih". Dalam hal ini, sampel terpilih merupakan pemustaka yang kebetulan menelusur/mencari informasi yang ada pada koleksi jurnal di perpustakaan Undiksha.

\section{Instrumen Pengumpulan Data}

Ada tiga jenis metode pengumpulan data yang digunakan dalam penelitian ini yaitu angket, pedoman wawancara dan lembar observasi. Untuk lebih jelasnya, berikut adalah tabel matrik pengumpulan data yang memuat sumber data, instrumen/alat pengumpulan data, jenis data, dan waktu penerapannya.

Tabel 1 Matriks Pengumpulan Data

\begin{tabular}{llll}
\hline Instrumen & $\begin{array}{c}\text { Sumber } \\
\text { data }\end{array}$ & \multicolumn{1}{c}{ Jenis data } & Waktu penerapan \\
\hline Angket & Pemustaka & $\begin{array}{l}\text { Respon pemustaka } \\
\text { terhadap program OPAC } \\
\text { jumal }\end{array}$ & $\begin{array}{l}\text { Pasca penerapan } \\
\text { program OPAC jurnal }\end{array}$ \\
\hline $\begin{array}{l}\text { Pedoman } \\
\text { wawancara }\end{array}$ & Pemustaka & $\begin{array}{l}\text { Respon pemustaka, } \\
\text { terhadap program OPAC } \\
\text { jumal }\end{array}$ & $\begin{array}{l}\text { Pasca penerapan } \\
\text { program OPAC jurnal }\end{array}$ \\
\hline $\begin{array}{l}\text { Panduan } \\
\text { observasi }\end{array}$ & Pemustaka & $\begin{array}{l}\text { Catatan perilaku } \\
\text { pemustaka dalam } \\
\text { merespon program OPAC }\end{array}$ & $\begin{array}{l}\text { Saat penelusuran } \\
\text { menggunakan program } \\
\text { OPAC }\end{array}$ \\
\hline
\end{tabular}




\section{Angket}

Alat ukur utama penelitian ini berbentuk angket/kuesioner. Angket tersebut memiliki 37 butir pernyataan yang terdiri atas aspek kognitif, afektif, dan konatif. Ke-37 butir pernyataan tersebut memancing respons responden terkait dengan pemakaian program OPAC jurnal dalam penelusuran.

Angket dikembangkan melalui beberapa tahap yaitu: (1) penyusunan kisi-kisi angket, (2) penyusunan instrumen penilaian, (3) validasi isi dengan penilaian ahli dan juga penilaian pemakai, (4) revisi instrumen, dan (5) pengumpulan data sesungguhnya.

\section{Kisi-Kisi Angket Sikap}

Berikut adalah tabel kisi-kisi skala sikap pemustaka terhadap program OPAC jurnal yang terdiri atas dimensi/aspek, deskriptor dan butir pernyataan angket yang berjumlah 37 .

Tabel 2 Kisi-Kisi Skala Sikap terhadap Program OPAC Jurnal

\begin{tabular}{|c|c|c|c|c|c|}
\hline \multirow[t]{2}{*}{ NO } & \multirow{2}{*}{ DIMENSIAASPEK } & \multirow{2}{*}{ DESKRIPTOR } & \multicolumn{2}{|c|}{ BUTIR } & \multirow{2}{*}{$\underset{\text { A.H }}{\text { JUML }}$} \\
\hline & & & Positif & Negatif & \\
\hline $\mathbf{1}$ & $\begin{array}{l}\text { KEMUDAHAN/ } \\
\text { USABILITY }\end{array}$ & Kemudahan akses & $\begin{array}{l}5,10,13 \\
26,30, \\
31\end{array}$ & $\begin{array}{l}22,33 \\
34\end{array}$ & 9 \\
\hline 2 & $\begin{array}{l}\text { KEBERMANFAATAN } \\
\text { USEFULNESS }\end{array}$ & $\begin{array}{l}\text { Relevansi } \\
\text { program/kegunaan }\end{array}$ & $\begin{array}{l}2,6,7,8 \\
9,29,32 \\
37\end{array}$ & 11,24 & 10 \\
\hline 3 & TAMPILAN MUKA & $\begin{array}{l}\text { Desain program } \\
\text { menarik }\end{array}$ & 1,4 & 23 & 3 \\
\hline 4 & EFISIENSI & $\begin{array}{l}\text { Kecepatan dan } \\
\text { kecermatan program } \\
\text { tanpa membuang } \\
\text { waktu, tenaga maupun } \\
\text { biaya }\end{array}$ & $3,27,28$ & 21 & 4 \\
\hline 5 & KEAKURATAN & $\begin{array}{l}\text { Program mampu } \\
\text { beroperasi secara teliti, } \\
\text { tepat dan benar sesuai } \\
\text { tujuan desain. }\end{array}$ & $\begin{array}{l}16,17,1 \\
8\end{array}$ & 35 & 4 \\
\hline 6 & KEPUASAN & $\begin{array}{l}\text { Program mampu } \\
\text { memberikan rasa } \\
\text { senang/gembira } \\
\text { kepada pengguna } \\
\text { karena sudah terpenuhi } \\
\text { hasrat hatinya }\end{array}$ & $\begin{array}{l}12,14,1 \\
5 \\
19,20,2 \\
9\end{array}$ & 36 & 7 \\
\hline & & JUMLAH & & & 37 \\
\hline
\end{tabular}

\section{Penskoran Angket}

Angket tersebut memakai tingkat pengukuran ordinal dengan kategori jawaban terdiri atas 5 tingkat. Untuk analisis secara kuantitatif alternatif jawaban diberi skor dari nilai 1-5: sangat tidak setuju (STS), tidak setuju (TS), netral $(\mathrm{N})$, setuju (S) dan sangat setuju (SS).

\section{Pedoman Wawancara}

Pedoman wawancara digunakan di dalam melakukan wawancara yang berisikan daftar pertanyaan yang bersifat terbuka untuk memperoleh data yang mendalam (Suyanto:2007). Pedoman wawancara disusun berdasarkan ketiga komponen sikap yaitu kognitif, afektif, dan konasi.

Jurnal IImu Sosial dan Humaniora | 463 
Wawancara dilakukan sebagai tindak lanjut dari temuan yang didapat melalui angket yang dianggap perlu untuk dicermati secara luas dan rinci.

\section{Lembar Observasi}

Lembar observasi/pengamatan digunakan untuk memantau responrespons yang ditunjukkan oleh pemustaka pada saat mereka melakukan penelusuran dengan menggunakan program OPAC jurnal.

\section{Teknik Analisis Data}

Ada dua jenis data yang diperoleh melalui penelitian ini yaitu data kuantitatif dan kualitatif. Data yang diperoleh melalui angket merupakan data kuantitatif. Data yang diperoleh melalui angket dianalisis melalui statistik deskriptif sederhana. Sebaliknya, data yang dikumpulkan melalui pedoman wawancara dan panduan observasi merupakan data kualitatif. Data ini kemudian dianalisis dan dijelaskan secara deskriptif. Rekapitulasi data angket Misalnya, dari 100 responden yang merespon ditemukan distribusi sebagai berikut: menjawab $5=20$, menjawab $4=30$, menjawab $3=10$, menjawab $2=40$, menjawab $1=10$

Maka akan dihitung:

\begin{tabular}{|lll|}
\hline Jumlah skor untuk 20 responden menjawab 5 & $=$ & 100 \\
Jumlah skor untuk 30 responden menjawab 4 & $=$ & 120 \\
Jumlah skor untuk 10 responden menjawab 3 & $=$ & 30 \\
Jumlah skor untuk 40 responden menjawab 2 & $=$ & 80 \\
Jumlah skor untuk 10 responden menjawab 1 & $=$ & $\underline{10}$ \\
Jumlah skor & & $=340$ \\
Jumlah ideal untuk item tersebut adalah (skor & $5 \times 100$ & $=500$ \\
tertinggi) & & \\
Jumlah skor terendah & $1 \times 100$ & $=100$ \\
& & \\
\hline
\end{tabular}

Jika diposisikan dalam respon angket, skor data tersebut terletak diantara Netral dan Setuju

Jika skor tersebut kemudian dikonversikan ke dalam bentuk persentase, ditemukanlah nilai berikut:

$340 / 500 \times 100 \%=68 \%$

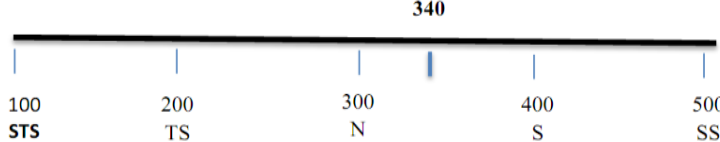

Persentase tersebut bisa dikategorikan sebagai cukup positif, dengan kriteria interpretasi skor berikut: 
Tabel 3 Persentase Skor

\begin{tabular}{|ll|}
\hline $\mathbf{8 5} \%-100 \%$ & Sangat positif \\
$\mathbf{7 0} \%-\mathbf{8 4} \%$ & Positif \\
$55 \%-69 \%$ & Cukup positif \\
$\mathbf{4 5} \%-\mathbf{5 4} \%$ & Negatif \\
$\mathbf{0 \%} \%-\mathbf{4 4 \%}$ & Sangat negatif \\
\hline
\end{tabular}

\section{HASIL PENELITIAN}

\section{Pengembangan Angket Skala Sikap}

Angket

dikembangkan

berdasarkan tabel 2 tentang kisi-kisi angket, yang memuat enam aspek utama pembuatan program yaitu kemudahan/usability,

kebermanfaatan/usefulness, tampilan muka, efisiensi, keakuratan, dan kepuasan pemakai program. Keenam aspek tersebut dikembangkan lebih lanjut menjadi 37 butir pernyataan. Angket tersebut kemudian divalidasi oleh para pakar yang berkualifikasi.

\section{Validasi Kualitatif}

Validasi dilakukan untuk mengetahui kesesuaian dimensi dengan indikator/deskriptor perilaku terhadap butir pernyataan, serta kekuatan dan kelemahan dari angket yang sudah dikembangkan. Adapun aspek yang divalidasi adalah kesesuaian isi butir pernyataan, bahasa dan tampilan atau sajian dari angket tersebut. Untuk itu, pakar diberikan format validasi sebagai acuan untuk menuliskan hasil evaluasi mereka terhadap instrumen yang dinilai.

Berdasarkan penilaian tim ahli, maka dapat disimpulkan bahwa secara umum aspek angket yang divalidasi menunjukkan hasil yang baik.

Namun, khusus untuk poin b mengenai keterwakilan aspek dari sebuah komputer mendapatkan perhatian khusus dari tim ahli. Menurut para ahli, jumlah butir pernyataan untuk aspek yang menunjukkan keakuratan sebuah program perlu untuk ditambah agar berimbang dengan jumlah butir lainnya.

Sedangkan dari aspek bahasa dan aspek tampilan/sajian angket, keempat ahli berpendapat bahwa bahasa yang digunakan sudah mengikuti kaidah penulisan EYD.

Pakar II juga menyarankan merevisi pilihan jawaban pada angket untuk jawaban $\mathrm{N}$ (netral) supaya diganti dengan pilihan KS (kurang setuju). Disamping itu, pakar II juga menyatakan kelebihan dari angket terutama pada aspek tampilan dan isi.

Berdasarkan hasil validasi dari tim ahli, ada dua aspek penting yang perlu mendapatkan perhatian dari peneliti, terutama mengenai hal penambahan butir pernyataan untuk dimensi keakuratan dan merevisi redaksi pengantar pada angket.

\section{Validasi Kuantitatif}

Validasi kuantitatif juga dilakukan oleh tim ahli dan hasil perhitungannya akan diolah dengan bantuan program spss. Validasi ini dilakukan untuk mengetahui validitas dan reliabilitas sebuah instrumen. Dengan demikian diharapkan akan terdapat kesesuaian antara aspek (secara teoritis) yang diukur dan deskriptor yang merupakan cerminan perilaku. Validasi kuantitatif dari keempat ahli dapat ditunjukkan melalui tabel 4 berikut.

Jurnal IImu Sosial dan Humaniora | 465 
Tabel 4 Hasil Penilaian Kuantitatif dari Pakar

\begin{tabular}{|c|c|c|c|c|c|c|c|c|c|c|}
\hline \multirow{2}{*}{$\begin{array}{l}\text { Pakar } \\
\text { Item }\end{array}$} & \multirow[b]{2}{*}{ I } & \multirow[b]{2}{*}{ II } & \multirow[b]{2}{*}{ III } & \multirow[b]{2}{*}{ IV } & \multirow[b]{2}{*}{ Rerata } & \multicolumn{3}{|c|}{ Validitas } & \multicolumn{2}{|c|}{ Reliabillitas } \\
\hline & & & & & & $\underset{\text { hitung }}{\mathbf{r}}$ & $\underset{\text { tabel }}{\mathbf{r}}$ & Status & $\begin{array}{l}\text { Var } \\
\text { Butir }\end{array}$ & $\begin{array}{l}\text { Alpha } \\
\text { Cronbach }\end{array}$ \\
\hline 1 & 4 & 4 & 4 & 5 & 4.25 & 0,985 & 0,81 & Valid & 0,250 & 0,985 \\
\hline 2 & 3 & 3 & 4 & 5 & 3.75 & 0,943 & 0,81 & Valid & 0,917 & \\
\hline 3 & 3 & 3 & 3 & 5 & 3.5 & 0,985 & 0,81 & Valid & 1.00 & \\
\hline 4 & 3 & 4 & 4 & 5 & 4 & 0,854 & 0,81 & Valid & 0,667 & \\
\hline 5 & 4 & 3 & 4 & 5 & 4 & 0,854 & 0,81 & Valid & 0,667 & \\
\hline 6 & 4 & 4 & 4 & 5 & 4.25 & 0,985 & 0,81 & Valid & 0,250 & \\
\hline 7 & 4 & 4 & 4 & 5 & 4.25 & 0,985 & 0,81 & Valid & 0,250 & \\
\hline 8 & 3 & 3 & 4 & 5 & 3.75 & 0,943 & 0,81 & Valid & 0,917 & \\
\hline 9 & 4 & 4 & 4 & 5 & 4.25 & 0,985 & 0,81 & Valid & 0,250 & \\
\hline 10 & 4 & 4 & 4 & 5 & 4.25 & 0,985 & 0,81 & Valid & 0,250 & \\
\hline 11 & 4 & 4 & 4 & 5 & 4.25 & 0,985 & 0,81 & Valid & 0,250 & \\
\hline 12 & 4 & 4 & 4 & 5 & 4.25 & 0,985 & 0,81 & Valid & 0,250 & \\
\hline 13 & 4 & 4 & 4 & 5 & 4.25 & 0,985 & 0,81 & Valid & 0,250 & \\
\hline Rerata & 3,7 & 3,7 & 3,9 & 5 & 4,07 & & & & & \\
\hline
\end{tabular}

Tabel 4 menunjukkan bahwa pakar I dan II memberikan skor 4 sebanyak 9 kali dan skor 3 sebanyak 4 kali, sehingga rata-rata dari pakar I dan II adalah 3,7. Pakar III memberikan skor 4 sebanyak 12 kali dan skor 3 sebanyak 1 kali, sehingga rata-ratanya adalah 3,9. Terakhir pakar IV memberikan skor 5 secara mutlak dan untuk itu memiliki rata-rata 5. Rerata skor keseluruhan adalah 4,07.

Berdasarkan tabel 4 tersebut dapat dilihat bahwa semua item tergolong valid karena $r$ hitung lebih besar daripada $r$ tabel. Dari hasil perhitungan reliabilitas dengan menggunakan alpha cronbach adalah 0,985 .

\section{Validasi Pemakai}

Validasi pemakai dilakukan setelah dilakukan validasi dari tim ahli. Hal ini dilakukan untuk melihat kejelasan dan keterbacaan instrumen angket bagi responden, maka dilakukan validasi pemakai. Ada sepuluh pemakai yang melakukan penilaian terhadap angket yang dirancang. Validasi ini dilakukan secara kualitatif. Responden diwawancarai setelah membaca angket skala sikap yang diberikan. Hal ini penting dilakukan merujuk pada penilaian pemakai terhadap aspek isi, bahasa dan tampilan angket sebelum disebar menunjukkan kualitas sebuah angket.

Berdasarkan hasil wawancara terhadap pemakai, dinyatakan bahwa secara umum instrumen sudah baik.

Jurnal IImu Sosial dan Humaniora | 466 
Instrumen sudah mencerminkan kesesuaian antara aspek yang ingin diukur dan pernyataan item yang dirancang. Menurut pemakai petunjuk penggunaan angket sudah jelas. Dari aspek bahasa, pemakai menilai bahwa bahasa yang digunakan dalam instrumen sesuai dengan kaidah bahasa Indonesia. Bahasa yang digunakan dalam instrumen jelas dan mudah dimengerti, begitu juga terhadap bahasa dalam petunjuk penggunaan instrumen.

Terhadap aspek tampilan, pemakai juga memberikan penilaian yang baik. Menurut pemakai, format desain instrumen sesuai dengan konvensi pada umumnya. Desain tampilan instrumen (format kertas, pengetikan dan kualitas cetak) sesuai bagi pemakai. Pemakai sangat setuju dengan model kolom pada pilihan jawaban karena memudahkan mereka dalam menjawab angket. Pemakai berpendapat bahwa angket ini praktis dan mudah digunakan.

Berdasarkan penilaian pemakai tersebut, peneliti menyimpulkan angket siap untuk disebar kepada responden.

\section{Data Angket}

Berikut adalah hasil perhitungan terhadap angket yang disebar ke 100 pemustaka yang menggunakan OPAC Jurnal.

Tabal E Taral skar f ar hampanar

\begin{tabular}{|c|c|c|c|c|}
\hline ROMUPGES & IIENI & БйH TOTAL & 3 & RERAT/S \\
\hline \multirow[t]{11}{*}{ REC्थाTIF } & II & 4 [D] & 50 & $\mathrm{RS}$ \\
\hline & 2 & 475 & E5 & \\
\hline & 3 & $4+5$ & 59 & \\
\hline & + & 3Is & 85 & \\
\hline & 5 & 450 & 90 & \\
\hline & 5 & 475 & 95 & \\
\hline & 7 & $4 \pi 0$ & 94 & \\
\hline & 5 & 4 40] & 6I & \\
\hline & 9 & 440 & 54 & \\
\hline & 10 & 410 & $8+$ & \\
\hline & 11 & 415 & 55 & \\
\hline \multirow[t]{14}{*}{ AFERIIF } & 12 & 4 40] & 8II & 71.45 \\
\hline & 13 & 472 & $\mathrm{R.4}$ & \\
\hline & 14 & 410 & 42 & \\
\hline & IS & 4 पDI & Bd & \\
\hline & 16 & 450 & 90 & \\
\hline & 17 & 465 & 33 & \\
\hline & $1 \mathrm{H}$ & 435 & 57 & \\
\hline & 19 & 475 & E5 & \\
\hline & $2 \pi$ & 415 & 53 & \\
\hline & 21 & 375 & 75 & \\
\hline & 27 & $4[0]$ & EI & \\
\hline & 23 & 400 & EI] & \\
\hline & 24 & $3 \mathrm{Fl}$ & 76 & \\
\hline & 35 & 35 & 79 & \\
\hline \multirow[t]{12}{*}{ KपदARI } & 25 & 425 & E5 & 55.97 \\
\hline & 26 & 457 & 90 & \\
\hline & 27 & 435 & 57 & \\
\hline & $2 \mathrm{H}$ & $40]$ & Ba & \\
\hline & 29 & 412 & B2.4 & \\
\hline & $3 \pi$ & 45 & 91 & \\
\hline & 31 & 455 & 91 & \\
\hline & 32 & 4DI] & BII & \\
\hline & 33 & 415 & 55 & \\
\hline & 34 & 475 & 95 & \\
\hline & 36 & 33 & $\operatorname{se}$ & \\
\hline & 37 & 451 & 90 & \\
\hline IOIAL. & & LSEs9 & 84.1567s & \\
\hline
\end{tabular}


Berdasarkan tabel 5, skor total dari 100 responden terhadap ke-37 butir item sebesar 15.569 dengan tingkat persentase sebesar 84,15676\%. Di samping itu pula, tabel 5 menunjukkan persentase per komponen yaitu: $85 \%$ untuk aspek kognitif, 82,45\% untuk aspek afektif, serta 85,37\% untuk aspek konasi.

\section{Hasil Wawancara}

Peneliti menggunakan metode wawancara untuk menggali lebih dalam sikap pemustaka terhadap program OPAC Jurnal. Secara umum, pemustaka memiliki sikap sangat positif terhadap keberadaan OPAC Jurnal. Pemustaka merasa lebih dimudahkan dalam melakukan penelusuran jurnal jika dibandingkan dengan sebelum tersedianya layanan OPAC digital ini.

\section{Hasil Observasi}

Berdasarkan hasil observasi, teridentifikasi adanya dua tipe perilaku pemustaka dalam menelusur yaitu pemustaka yang masih tergolong konvensional dan digital. Pemustaka konvensional cenderung untuk langsung menuju ke rak koleksi atau browsing pada katalog buku/manual untuk mendapatkan jurnal yang diinginkan. Namun, pemustaka yang tergolong kaum digital langsung menanyakan ketersediaan OPAC kepada staff jurnal sebelum melakukan penelusuran. Melalui arahan dan bimbingan teknis dari staff pengelola jurnal, pemustaka baik yang konvensional maupun digital bisa lebih percaya diri untuk menelusur menggunakan OPAC Jurnal secara mandiri. Mereka sangat puas dengan layanan yang tersedia. Perasan senang akan kemudahan akses yang tersedia dalam layanan jurnal berimplikasi pada keinginan pemustaka untuk mengajak pemustaka lain untuk mencari jurnal dengan memanfaatkan program OPAC Jurnal.

\section{PEMBAHASAN \\ Validasi Angket}

Berdasarkan hasil validasi kualitatif dari tim pakar, angket sudah bisa dikatakan memiliki kualitas yang baik dengan sedikit revisi yang dilakukan dengan cara penambahan butir item pada aspek keakuratan dan memperbaiki kata pengantar pada angket. Hasil perhitungan kuantitatif dengan bantuan program SPSS menunjukkan bahwa rerata dari pakar I dan II adalah masing-masing 3,7; pakar III 3,9 dan pakar IV 5. Rerata keseluruhan dari pakar menunjukkan besaran 4,07. Hal ini mengindikasikan bahwa penilaian para ahli sangat baik dan mencerminkan penilaian yang tidak jauh berbeda antara pakar satu dan lainnya. Dengan demikian hasil rerata ini dapat dijadikan acuan kuat dalam analisis dan kesimpulan.

Nilai validitas dan reliabilitas hitung angket lebih tinggi daripada nilai tabel dan dengan alpha cronbach sebesar 0,985, sehingga dapat dikategorikan bahwa angket memiliki kualitas yang baik.

\section{Sikap Pemustaka terhadap Program OPAC Jurnal}

Tabel 5 menunjukkan sikap pemustaka terhadap OPAC Jurnal dalam mempermudah penelusuran pada perpustakaan Universitas Pendidikan Ganesha. Secara kognitif, skor yang diperoleh adalah $85 \%$ yang berada pada kategori sangat positif. Skor untuk aspek

Jurnal IImu Sosial dan Humaniora | 468 
afektif adalah $82,45 \%$ yang berada pada kategori positif. Skor untuk aspek konasi adalah $84,45 \%$ yang berada pada kategori sangat positif. Secara keseluruhan, skor rerata untuk skala sikap adalah $84,16 \%$ yang berada pada kategori positif (lihat tabel 3 persentase skor angket).

Berdasarkan hasil wawancara, pemustaka merasakan kemudahan dan kebermanfaatan dalam penelusuran menggunakan OPAC Jurnal. Menurut pendapat mereka, penelusuran menjadi lebih efektif jika dibandingkan sebelum adanya OPAC. Pemustaka berpendapat OPAC ini sangat relevan dengan permasalahan penelusuran jurnal yang sangat tidak efisien. Program OPAC Jurnal ini dapat membantu penelusuran dengan cepat dan cermat tanpa membuang-buang waktu, tenaga maupun biaya. Di samping itu, pemustaka juga berpendapat OPAC Jurnal ini cukup akurat karena program dapat beroperasi secara teliti, tepat dan benar sesuai tujuan yang di disain, sehingga mereka merasa puas dengan layanan yang tersedia. Dengan demikian, dapat disimpulkan bahwa sikap pemustaka terhadap OPAC Jurnal adalah positif.

Selain menggunakan metode angket dan wawancara, peneliti juga menggunakan metode observasi terhadap kecenderungan perilaku pemustaka dalam menggunakan OPAC Jurnal. Hasil observasi menunjukkan bahwa bagi pemustaka yang belum mengetahui keberadaan OPAC Jurnal, mereka cenderung untuk langsung menelusur di rak koleksi. Di samping itu pula, jika mereka tidak dapat menemukan jurnal yang dicari, maka mereka akan menggunakan bantuan katalog manual/buku. Ketidakefektifan dalam mencari jurnal dirasakan oleh pemustaka karena katalog manual pun tidak dapat membantu penelusuran, mengingat informasi yang tersedia hanya mencantumkan nama jurnal, tahun, edisi maupun alamat jurnal bukan topik/subjeknya. Melalui arahan dan bimbingan staf pengelola jurnal, maka pemustaka tersebut diarahkan untuk menggunakan fasilitas OPAC Jurnal.

Di lain pihak, bagi pemustaka yang sudah mengetahui keberadaan OPAC Jurnal, mereka akan langsung menggunakan OPAC tanpa melihat lagi pada katalog manual. Pemustaka tersebut sudah merasakan kepuasan yang didapat melalui fasilitas OPAC digital ini. Perasaan puas terhadap kemudahan dan kebermanfaatan OPAC tersebut, meninggalkan kesan dan pengalaman pribadi yang kuat dalam menemukan jurnal yang dicari. Tidak jarang, pemustaka yang sudah mengetahui keberadaan layanan OPAC ini akan menginformasikan dan mengajak pemustaka lain datang ke layanan jurnal. Berdasarkan kecenderungan perilaku pemustaka tersebut maka dapat disimpulkan bahwa sikap yang ditunjukkan oleh pemustaka dapat digolongkan positif (lihat tabel 3).

Sejalan dengan hasil observasi, maka dapat diformulasikan bahwa terdapat dua tipe pemustaka yaitu yang tergolong konvensional dan digital. Ada perbedaan kecenderungan perilaku yang muncul merujuk pada kedua latar belakang pemustaka tersebut. Pemustaka konvensional cenderung untuk browsing pada katalog manual/buku atau langsung menuju ke rak. Sedangkan, pemustaka digital akan cenderung memanfaatkan OPAC Jurnal

Jurnal IImu Sosial dan Humaniora | 469 
saat menelusur jurnal. Perbedaan perilaku ini timbul, karena adanya perbedaan karakteristik dari pemustaka konvensional dan digital. Pemustaka digital memiliki karakteristik melakukan sesuatu serba cepat, serba online, menyukai kerja dalam bentuk paralel dan hypertext/random. Untuk merubah/mempengaruhi pemustaka konvensional, maka peran sosialisasi dan bimbingan teknis secara berkesinambungan perlu diupayakan oleh pihak pengelola perpustakaan. Hal ini dimaksudkan untuk mengarahkan, memberikan informasi dan membentuk pengalaman pribadi pemustaka dalam menggunakan OPAC Jurnal.

Berdasarkan hasil angket, wawancara dan observasi, maka dapat disimpulkan bahwa data yang diperoleh saling mendukung satu dengan lainnya.

Untuk penyederhanaan pembahasan tentang alur pembentukan sikap pemustaka terhadap OPAC Jurnal dapat digambarkan pada gambar 1 berikut.

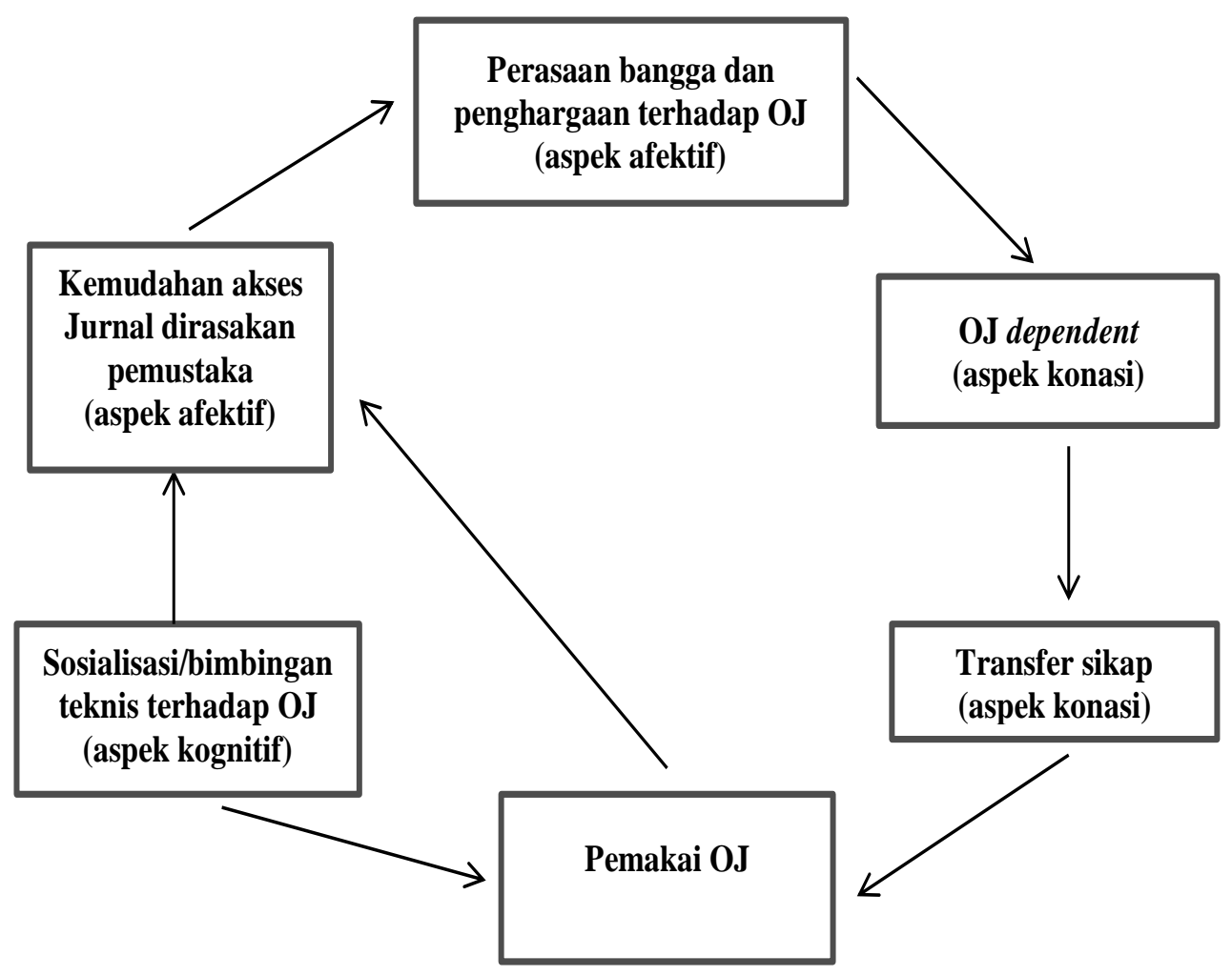

Gambar 1. Alur pembentukan sikap pemustaka terhadap OPAC Jurnal 
Gambar 1 memvisualisasikan alur pembentukan sikap pemustaka terhadap OPAC Jurnal disingkat OJ. Bimbingan teknis diberikan kepada pemustaka yang mencari jurnal. Melalui bimbingan ini pemusta dapat meningkatkan kepercayaan diri/pengetahuan/persepsi pemustaka terhadap keberadaan OJ. Pemustaka dapat merasakan kemudahan akses yang disediakan, sehingga menimbulkan kesan/pengalaman pribadi yang kuat. Pengalaman dengan kesan yang kuat dan dibingkai oleh situasi emosional yang dalam memunculkan perasaan bangga dan penghargaan terhadap OJ. Hal ini memicu adanya konsistensi perilaku pemustaka terhadap OJ atau dengan kata lain pemustaka sudah ketergantungan terhadap OJ (OJ dependent).

Sikap positif terhadap OPAC Jurnal berbasis subjek indexing ditunjukkan oleh pemakaian OPAC Jurnal secara konsisten tanpa adanya keinginan pemustaka untuk melihat/membandingkannya dengan katalog manual/buku ataupun keinginan untuk langsung ke rak koleksi.

Berdasarkan hasil analisis terhadap data yang diperoleh dari angket, wawancara dan observasi, maka peneliti selaku pengelola jurnal dan pimpinan perpustakaan sebagai pihak pengelola kebijakan hendaknya dapat dengan sengaja membentuk sikap positif pemustaka dalam upaya pelaziman yang terus menerus. Dalam pembentukan sikap positif pemustaka tersebut, ada beberapa hal yang menjadi kunci penting antara lain:

a. Pengalaman pribadi pemustaka. Kesan yang kuat, penghayatan dan tanggapan pemustaka menjadi dasar pembentukan sikap pemustaka. Perolehan pengalaman yang menyenangkan bagi pemustaka yang menelusur jurnal menggunakan bantuan OPAC Jurnal akan mempengaruhi sikap pemustaka terhadap program tersebut.

b. Pengaruh pemustaka lain. Pemustaka yang memiliki pengalaman pribadi yang mengesankan terhadap kebermanfaatan OPAC Jurnal akan berupaya untuk mentransfer apa yang dialami. Hal ini terlihat pada saat seorang pemustaka yang sudah mengenal OPAC Jurnal datang mengajak dan menginformasikan keberadaan layanan OPAC tersebut kepada pemustaka lainnya. Pengalaman baru yang didapat oleh pemustaka akan terus digulirkan ke pemustaka lainnya dan seterusnya.

c. Faktor emosional. Kesan yang kuat yang dibingkai oleh situasi emosi yang dalam (puas dan bangga) akan berpengaruh kuat terhadap pembentukan sikap pemustaka terhadap OPAC Jurnal.

d. Situasi lingkungan. Lingkungan yang serba digital yang disediakan oleh perpustakaan akan memiliki pengaruh yang cukup kuat terhadap keterarahan yang harus diikuti oleh pemustaka.

e. Media komunikasi. Pengumuman, sosialisasi dan pembinaan teknis tentang keberadaan OPAC Jurnal serta tata cara pemakaiannya berperan penting dalam menumbuhkan upaya pelaziman pihak pemustaka.

f. Institusi/lembaga perpustakaan. Peranan pimpinan perpustakaan Jurnal IImu Sosial dan Humaniora | 471 
dalam menerapkan suatu kebijakan akan mengarahkan pemustaka untuk mengikuti peraturan yang ada. Misalnya, mengharuskan pemustaka untuk browsing ke OPAC sebelum mengetahui tempat jurnal yang dicari, sehingga koleksi akan tetap tertata rapi dan terawat baik.

Dengan demikian, dapat disimpulkan bahwa ketiga komponen pembentuk sikap pemustaka terhadap OPAC Jurnal berjalan saling terkait satu dengan lainnya. Sikap pemustaka tidak akan bisa terbentuk berdasarkan penilaian dari salah satu komponen sikap tersebut. Komponen sikap kognitif (pengetahuan, keyakinan, kepercayaan) pemustaka akan diwarnai oleh komponen sikap afektif (perasaan suka/tidak suka), sehingga akan memicu kecenderungan perilaku pemustaka (aspek konasi) untuk menggunakan OPAC Jurnal. Hal inilah yang menentukan sikap atau penilaian pemustaka terhadap OPAC Jurnal.

\section{PENUTUP}

Berdasarkan hasil dan pembahasan, maka dapat disimpulkan bahwa sikap pemustaka secara umum dapat dikategorikan positif yaitu dengan rerata $84,15 \%$. Dibedakan lagi per komponen sikap dengan rincian: (1) aspek kognitif sebesar $85 \%$, sehingga dikategorikan sangat positif; (2) aspek afektif sebesar 82,45 \%, sehingga dikategorikan positif; dan (3) aspek konasi sebesar 85, $37 \%$, sehingga dikategorikan sangat positif. Dalam pembentukan sikap pemustaka terhadap OPAC Jurnal, ketiga komponen sikap ini terkait satu dengan lainnya. Komponen sikap kognitif (pengetahuan, kepercayaan, dan keyakinan) pemustaka akan mewarnai aspek afektif (perasaan suka/tidak suka), sehingga akan membingkai kecenderungan perilaku pemustaka (aspek konasi) terhadap OPAC Jurnal.

Penelitian ini dilakukan bertujuan untuk mengetahui sejauh mana penerimaan pemustaka terhadap suatu teknologi dalam hal ini OPAC Jurnal. Penerimaan ini dapat dilihat dari sikap positip pemustaka terhadap keberadaan OPAC Jurnal. Hal ini penting untuk diketahui oleh pengelola perpustakaan agar teknologi yang tercipta memang memiliki kebermanfaatan yang tinggi demi meningkatkan kepuasan pemustaka. Berdasarkan hasil yang diperoleh, untuk membentuk sikap positip pemustaka dan mengurangi keraguan sikap pemustaka untuk menggunakan OPAC Jurnal, maka perlu diupayakan keterlibatan pimpinan untuk mengadakan kegiatan sosialisasi dan bimbingan teknis secara berkelanjutan.

Selain itu, hasil penelitian ini diharapkan dapat dijadikan pedoman bagi peneliti lain yang ingin melakukan kajian sejenis.

\section{DAFTAR PUSTAKA}

Baron, Robert A. dan Dann Byrne. 2003. Social Psychology. New Jersey: Pearson Education, Inc.

Bungin, B. 2007. Metodologi Penelitian Kualitatif. Jakarta: PT Raja Grafindo Persada.

Cambridge Advanced Learner's Dictionary Third Edison. 2010. Microsoft Corporation.

Jurnal IImu Sosial dan Humaniora | 472 
Cresswell, Jon W. 2008. Educational Research: Planning, Conducting, and Evaluating Quantitative and Qualititative Research. New Jersey: Pearson Education, Inc.

Faisal, Sanapiah. 2008. Format-Format Penelitian Sosial. Jakarta: PT Rajagrafindo Persada

Hamad, I. 2010. Transformasi Kultural Menuju Masyarakat Informasi. Jurnal Dialog Kebijakan Publik. 10(35).

Suhardi, Basuki. 1996. Sikap Bahasa. Fakultas Sastra Universitas Indonesia.
Suyanto, Bagong dan Sutinah. 2007. Metode Penelitian Sosial: berbagai alternative pendekatan. Jakarta: Kencana Prenada Media Group.

Utami, Pramita. 2012. Pengembangan Program OPAC (Online Public Access Catalogue) Berbasis Subject Indexing dalam Mempermudah Penelusuran Jurnal pada Perpustakaan Universitas Pendidikan Ganesha. Laporan Penelitian yang Didanai Dana DIPA dan tidak dipublikasikan. Lembaga Penelitian Universitas Pendidikan Ganesha. 